\title{
A Review on Deteriorating Inventory Study
}

\author{
Ruxian Li ${ }^{1}$, Hongjie Lan ${ }^{1}$, John R. Mawhinney ${ }^{2}$ \\ ${ }^{1}$ School of Economics and Management, Beijing Jiaotong University, Beijing, China; ${ }^{2}$ Business School, Duquesne University, \\ Pittsburgh, USA. \\ Email:*hjlan@bjtu.edu.cn
}

Received September $2^{\text {nd }}, 2009$; revised October 21 $1^{\text {st }}$ 2009; accepted November $29^{\text {th }}, 2009$.

\begin{abstract}
To provide a comprehensive introduction about the deteriorating items inventory management research status, this paper reviews the recent studies in relevant fields. Compared with the extant reviews (Raafat 1991; S.K.Goyal 2001), this paper reviews the recent studies from a different perspective. First, this paper proposes some key factors which should be considered in the deteriorating inventory studies; then, from the perspective of study scope, the current literatures are distinguished into two categories: the studies based on an enterprise and those based on supply chain. Literatures in each category are reviewed according to the key factors mentioned above. The literature review framework in this paper provides a clear overview of the deteriorating inventory study field, which can be used as a starting point for further study.
\end{abstract}

Keywords: Deteriorating Items, Inventory Model, Literature Review

\section{Introduction}

Deteriorating items are common in our daily life; however, academia has not reached a consensus on the definition of the deteriorating items. According to the study of Wee HM in 1993 [1], deteriorating items refers to the items that become decayed, damaged, evaporative, expired, invalid, devaluation and so on through time. According to the definition, deteriorating items can be classified into two categories. The first category refers to the items that become decayed, damaged, evaporative, or expired through time, like meat, vegetables, fruit, medicine, flowers, film and so on; the other category refers to the items that lose part or total value through time because of new technology or the introduction of alternatives, like computer chips, mobile phones, fashion and seasonal goods, and so on. Both of the two categories have the characteristic of short life cycle. For the first category, the items have a short natural life cycle. After a specific period (such as durability), the natural attributes of the items will change and then lose useable value and economic value; for the second category, the items have a short market life cycle. After a period of popularity in the market, the items lose the original economic value due to the changes in consumer preference, product upgrading and other reasons.

The inventory problem of deteriorating items was first studied by Whitin [2], he studied fashion items deteriorating at the end of the storage period. Then Ghare and
Schrader [3]concluded in their study that the consumption of the deteriorating items was closely relative to a negative exponential function of time. They proposed the deteriorating items inventory model as stated below:

$$
\frac{d I(t)}{d t}+\theta I(t)=-f(t)
$$

In the function, $\theta$ stands for the deteriorating rate of the item, $I(t)$ refers to the inventory level at time $t$ and then $f(t)$ is the demand rate at time t. This inventory model laid foundations for the follow-up study. Raafat [4] and Goyal and Giri [5] made comprehensive literature reviews on deteriorating inventory items in 1991 and 2001 respectively.

From a different perspective, this paper reviews the recent trends in deteriorating inventory studies. Figure 1 presents the factors used to analyze and organize this review. From the perspective of scope, we make a distinction between the studies which focus on the deteriorating items inventory study in a single enterprise from those studies whose focus is on studying the deteriorating items inventory problems across a supply chain. The former is the focus of the early stage in the deteriorating items study and the latter now is attracting more and more attention from the researchers. From the perspective of the factors which should be taken into consideration in deteriorating items inventory study, we involve the important factors such as demand, deteriorating rate and 


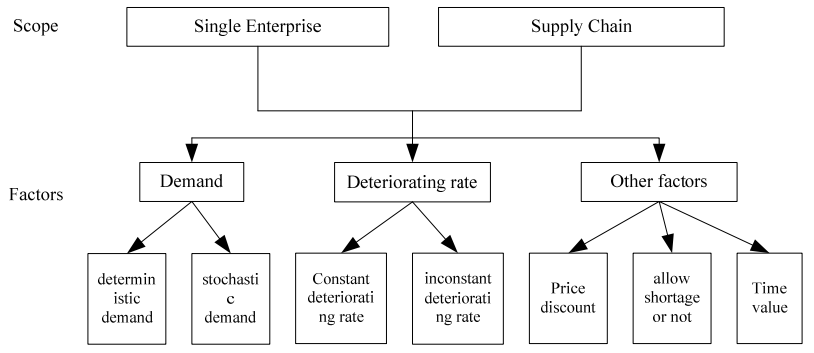

Figure 1. Deteriorating items inventory literature and its relation in the review

other factors such as price discount, allow shortage or not, inflation, time-value of money and so on in our study. By way of integrating different factors in different scope (in a single enterprise or across a supply chain), different models can be established.

This paper is organized as follow. Section two discusses key factors which should be taken into consideration in the deteriorating inventory study. Section three presents an overview on deteriorating items inventory study in a single enterprise. For the purpose of classification, three lines of research can be distinguished: the first and the second lines study the inventory problems in the enterprises which sell deteriorating items. The main difference between the two lines is that the first line involves a warehouse while the second one involves two warehouses. The third line reviews the produce and inventory problems in the deteriorating items manufacturers. The studies on the deteriorating items inventory problems from the perspective of the supply chain are sketched in section four. Then this paper discusses the directions of the future research.

\section{Key Factors in the Deteriorating Inventory Study}

Factors such as demand, deteriorating rate, and so on should be taken into consideration in the deteriorating inventory study. Among them, demand acts as driving force of the entire inventory system and the deteriorating rate stands for the characteristics of the deteriorating items. Other factors like price discount, allow shortage or not, inflation, and the time-value of money are also important in the study of deteriorating items inventory. By making different combinations of these factors stated above, we can get different inventory models.

\subsection{Demand}

Acting as the driving force of the whole inventory system, demand is a key factor that should be taken into consideration in an inventory study. There are mainly two categories demands in the present studies, one is deterministic demand and the other is stochastic demand. Constant demand [6,7], time-dependent demand [8,9] inventory level-dependent demand [10-13] and price-dependent demand [14] are all deterministic demand. Among them, ramp type demand is a special type of time-dependent demand. Hill [15] was the first to introduce the ramp type demand to the inventory study. Then Mandal and Pal [16] introduced the ramp type demand to the inventory study of the deteriorating items. After that, many researchers have extensively studied this type of demand $[17,18]$. Stochastic demand includes two types of demands: the first type characterized by a known demand distribution and on the contrary the second type characterized by arbitrary demand distribution.

\subsection{Deteriorating Rate}

Deteriorating rate is another key factor in the study of deteriorating items inventory, which describes the deterioration nature of the items. When it comes to the study of deteriorating rate, there are several situations. In the early stage of the study, most of the deteriorating rates in the models are constant, such as Ghare and Schrader [3], Shah and Jaiswal [19], Aggarwal [20], Padmanabhana and Vratb [21], and Bhunia and Maiti [22]. In recent research, more and more studies have begun to consider the relationship between time and deteriorating rate. In this situation there are several scenarios; including deteriorating rate is a linear increasing function of time [23,24], deteriorating rate is two-parameter Weibull distributed $[25,26]$, deteriorating rate is three-parameter Weibull distributed [27], and deteriorating rate is other function of time [28].

\subsection{Other Factors}

Beside demand and deteriorating rate, other factors like price discount, allow shortage or not, inflation, and time-value of money are also important factors. Price discount is an important strategy which the seller always uses to encourage the buyer to purchase in large quantities; many researchershave taken this factor into consideration in deteriorating items inventory modeling. Allowing shortage or not is another factor which researchers always focus on. Among them, some studies supposed that shortage is not allowed [29], the rest supposed that shortage is allowed and then corresponding inventory strategy can be made according to the two assumptions respectively. In fact, shortages usually happen in our daily life and what's more, in the circumstance of high deteriorating rate, the demand may need to be backlogged to reduce cost due to deterioration, so there are more studies that concentrate on the assumption that shortage is allowed. There are two cases when dealing with the shortage, one case supposes that the shortage items are totally backlogged [30,31] and the other case supposes that the shortage items are partly backlogged, that is to say, the customers are only willing to accept part of the items that are out of stock this period and can only be supplied by 
the seller in the next period. There are some different considerations in dealing with the backlogging function. In some of the studies, the backlogging function was assumed to be closely relative to the amount of demand backlogged [32], therefore the more the amount of demand backlogged, the smaller the demand to accept backlogging would be. While in our real life, for deteriorating items with short life time, the waiting time for the next replenishment is the main factor for deciding whether the backlog will be accept or not and when we are willing to accept the backlog, what is the accepting proportion? It is easy for us to know that the willingness of a customer to wait for backlogged items during a shortage period declines with the length of the waiting time. In order to reflect this phenomenon, some studies [33-35] developed inventory models in which the backlogging rate is a function of waiting time.

Trade credit is another factor. Trade credit (permissible delay in payment) is a widely used business strategy. To suppliers, trade credit helps to expand sale but it also adds to the risk of bad debts at the same time. To buyers, trade credit provides a very big advantage, due to the fact that they do not have to pay the seller immediately after receiving the items, but instead can delay their payment until the end of the allowed period. The buyer pays no interest during the agreed time for payment, but it increases the risk of deterioration cost when large amounts are purchased. However, both sellers and buyers need to reach trade-off between the advantages and disadvantages they can get from this inventory policy. At present, there are three kinds of trade credit, in the first case, the length of the credit period is fixed [36-38], in the second case, the length of the credit period is closely relative to the ordering quantity [39-41]. In the third case, the sellers provide trade credit to part of the ordering quantity and the purchase cost of the rest quantity should be paid immediately after receiving the items.

Inflation and time value of money have also attracted attention of researchers. Taking the two factors into consideration is of vital importance. With the integration of the global economy, the economic relationships among countries are closer and the mutual influences are deep. Currency's purchasing power will change from time to time and inflation should not be neglected. Many researchers [14,44-47] have made complementally comprehensive consideration in deteriorating items modeling.

\section{Deteriorating Items Inventory Study in a Single Enterprise}

Inventory cost is an important part of the enterprise operation cost. For deteriorating items, especially those with high deteriorating rate, deterioration is a key characteristic and its impact on modeling of inventory systems cannot be neglected. So the deterioration rate should be taken into consideration in the development of inventory strategy. For different kinds of enterprises, the emphasis on the deteriorating items inventory study is different. For the seller of deteriorating items, the current studies can be divided into two types; the first type emphasizes the inventory strategies for the retailer of the deteriorating items, the second type focuses on the inventory policy under a two-warehouse system. For the manufactures of deteriorating items, the current emphasis is on developing an optimal production-inventory strategy. So, this paper has divided the present studies on deteriorating items inventory for a single enterprise into three categories as stated above.

\subsection{Deteriorating Inventory Strategy}

The sellers of deteriorating items such as retailers must frequently assess the replenishment strategy for deteriorating items. Deteriorating items have a shorter life time compare with other items. In order to avoid the loss due to damage or expiration, it is of vital importance to develop a proper inventory strategy. Many researchers have conducted extensive studies on the deteriorating inventory strategy. Compared with normal inventory models, besides demand, deteriorating rate is another key factor that impacts significantly on an inventory management system. So when discussing models below, this paper will mainly concentrate on demand and deteriorating rate, and other factors, such as price discount, inflation, and so on, will also be taken into consideration.

\subsubsection{Deterministic Demand}

Sarker, Jamal and Wang [48], Chang [49], Chung and Liao [50], Huang and Liao [51]), ZHANG, DAI and HAN [42], ZHANG, DAI, HAN and LI [52] all developed inventory models in which both the demand and deteriorating rate are constant. In their research, the buyer is allowed a delay period to pay for the items purchased. The purpose of their studies is to help the buyers to make economic inventory strategy decisions under the influence of trade credit. Although the constant demand assumption helps to simplify the problem, it is far from the actual situation where demand is always in change. In order to make research more practical, many researchers have studied other forms of demand. Among them, time-dependant demand has attracted considerable attention. WANG Sheng-dong and WANG jun-ping [53] developed a model to determine optimal ordering policy for deteriorating items under inflation, partial backlogging, and time-dependant demand. The effect of the time value of money was also considered in the paper. Panda, et al. [54] discussed an inventory model for a seasonal product. In the model, the demand rate is represented by a ramp-type time dependent function and the deteriorating rate is a constant. With the assumption that shortages are not allowed, the paper aimed to develop an optimal replenishment policy for retailer. In addition, Papachristos and Skouri [55], Chu and Chen [56], Khanra and Chaud- 
huri [57], Yang [58], Dye et al. [59] all conducted research on deteriorating items inventory under the premise that the demand is time-dependent.

Besides time, the inventory level is another factor that has a close relationship with demand. For some item types, the demand rate may fluctuate with the on-hand stock level. It is a common phenomenon that a large amount of goods displayed in the supermarket will lead the customers to buy more, so the demand is closely dependant on the inventory level. Gupta and Vrat [60] first proposed an inventory model in 1986 in which demand rate is stock-dependent. Then Mandal and Phaujdar [61] developed a production-inventory model for deteriorating items with the assumption that demand is a linear function of inventory level. Padmanabhan and Vrat [62] developed an EOQ model for deteriorating items with stock-dependant demand, they proposed three models: completely backlogging, partial backlogging and without backlogging, for the purpose of maximizing profit. In this paper, the backlogging function was assumed to be closely relative to the amount of demand backlogged. As we discussed before, in real life it is more common that the willingness of a customer to wait for a backlog during a shortage period declines with the length of the waiting time, that is to say, the longer the waiting time is, the less likely the customers willing to wait. Then in 2005, Dye and Ouyang [63] extend Padmanabhan's model (Padmanabhan and Vrat, 1995) by proposing a time-proportional backlogging rate. While the opportunity cost due to lost sales was not taken into consideration in Padmanabhan's model, Chung-Yuan Dye took considerable consideration in his improved model. Hou [64] established an inventory model for deteriorating items with stock-dependent demand rate and shortages under inflation and time discounting. There are also some who studied other types of demand, like price-dependent demand [65-67], inflation-dependent demand [68] and so on.

In fact, the real situation is complex and the demand is always affected by several factors such as time, inventory level, price, and so on. Balkhi and Benkherouf [69], Pal et al [70], Hsu et al [71] combined several of the factors together and considered the impact of the combination on the demand, in this premise the optimal inventory strategy was discussed. WEN et al [72] developed an inventory model in which the demand is affected by time and inflation. The aim of the paper is to determine the optimal replenishment strategy including the replenishment time and order quantities which minimize the present value of the total cost.

All the models discussed above have the characteristics of a constant deteriorating rate. While the constant rate simplifies the problems, it cannot reflect the real situation of the deterioration; in fact the deteriorating rate varies with time. Wee and Law [73] proposed a deteriorating inventory model which took into consideration the time-value of money and price-dependent demand. Papachristos and Skouri [74] considered a model where the demand rate is a function of the selling price and the backlogging rate is a time-dependent function. Both of them assumed that the deteriorating rate is two-parameter Weibull distributed. Dye et al [75] developed an inventory model for deteriorating items with price-dependent demand. In the model the deterioration rate is a function of time and shortages are allowed. The unsatisfied demand is partially backlogged and the backlogging rate is a negative exponential rate of the waiting time. The aim of the model was to maximize the profit, and according to the model, the inventory strategy, including price, economic ordering quantity and so on, can be determined. Then Dye et al [76] took the time-value of money into consideration and extended their earlier research. Chang, et al [77] established an EOQ model for deteriorating items. In the model the supplier provided trade credit to the purchaser on the condition that the order quantity was greater than or equal to the predetermined quantity. The paper proposed Taylor's series approximation to obtain the optimal order quantity and replenishment time. Liao [78] then amended the solution for the model proposed by Chun-Tao Chang, etc and developed an alternative approach to determine the optimal ordering policy. HUANG Wei-lai and HUANG song [79]studied the economic order quantity problem with deteriorating items taking time-value of money into consideration. In the problem, the deteriorating rate was two-parameter Weibull distributed and the demand rate is linear function of the inventory level. An optimal order quantity model with deteriorating items based on the minimization of total cost was established, taking account of time value of money.

\subsubsection{Stochastic Demand}

In fact, with the growing uncertainty in the modern business environment, the assumption of deterministic demand is far from truth, so stochastic demand has attracted more and more attentions.

It is common that when dealing with the stochastic demand, a large number of researchers make the assumption that the demand is Poisson distributed. S. KALPAKAM and S.SHANTHI $[80,81]$ analyzed inventory systems with Poisson demands for deteriorating items. With the assumption of constant demand, in solving the model, Zhu [82] proposed a data processing method in which the demand was accumulated, making the model easily solved by computer and then enhancing the practicality of the model. Li et al. [83] introduced the three-parameter weibull function to describe the characteristics of deterioration. In this paper, demand is supposed to be closely relative to deterioration, that is to say, the more items deteriorating, the less the demand will be. Beside this, shortages were allowed and totally backlogged. According to the model, the optimal inventory 
policy including the replenishment time, order quantity can be determined.

With the increasing complexity in the business environment, it is of vital importance for enterprises to take factors such as demand, price discounting, inflation, time-value of money, and so on into consideration in inventory decision making. The current studies have given considerable consideration to the factors stated above and so they play an important role in the inventory decision-making.

\subsection{Two Warehouse Deteriorating Inventory Study}

Two-warehouse inventory problem for deteriorating items is a main category in the current inventory study for deteriorating items. The storage capacity of an enterprise is limited and in some real life situations, when the supplier provides a price discount for bulk purchases, or when the item is a seasonal product, or when the order cost is high, or the demand goes up quickly, or the cost of out-stock is high, the buyer may purchase a large amount of an item [84]. When the amount of the purchased items exceeds the storage capacity of the enterprise's own warehouse (OW), the excess quantities have to be stored in a rented warehouse (RW). This is the real background of the twowarehouse inventory problem. There are some common assumptions in the two-warehouse inventory problem. It is often believed that the storage capability of the OW is limited but the storage capability of the rented warehouse (RW) is unlimited, and that the RW often provides a better preserving facility than the OW. So compared with the OW, the inventory cost in RW is higher but the deterioration rate is lower. According to these assumptions, it is easy for us to understand that in order to reduce the inventory cost; it will be a good choice to consume the items in the RW first and store items in OW before RW (last in first out policy, LIFO). A large number of researchers have studied in this area according to the assumptions stated above, such as [85], yang, S.L. and Zhou, Y.W. [86], Benkherouf [87] and so on.

Sarma [88] first studied the two-warehouse inventory problem for deteriorating items. In his study, the deteriorating item was first stored in the OW and the excess quantity was stored in the RW. Then in the inventory model an infinite replenishment rate was considered and shortages were allowed. Then Pakkala and Achary [89] extended Sarma's study to the situation of an infinite replenishment rate. Yang [90] considered a two-warehouse inventory problem for deteriorating items with constant demand rate and shortages under the circumstances of inflation. Then Yang [91] extended the former study and considered partial backlogging in the twowarehouse inventory model, in which the backlogging rate is closely relative to the waiting time. Then Hui-Ling
Yang compared the two two-warehouse inventory models based on the minimum cost approach and the result showed that the model 2 was less expensive than model 1 if partial backlogging and inflation are considered. QIU and LIANG [92]) developed a two-warehouse inventory model on the basis of minimum cost. In the model the factors such as a constant deteriorating rate and demand trade credit were taken into consideration. The numerical results can aid the manager to decide the order quantity, order cycle, and so on.

All the two-warehouse inventory models discussed above have the characteristic of constant demand; in fact many other researchers have studied other types of demand, like time-dependent demand, etc. XU and LI [93] proposed an optimal inventory policy for a two-warehouse inventory model with time-dependent demand and constant deterioration rate. In the model, shortages are not allowed and according to the model the total order quantity and the quantity stored in the rented warehouse in a cycle time can be determined. Dey et al. [94] studied the two-warehouse inventory problem from the perspective of retailers. In their study, the storage capability of OW which is always located at a busy market place is limited. So the excess items should be stored in a RW which may be located away from the market place. The paper assumed that the inventory cost in the RW is greater than $\mathrm{OW}$ and so the items are first stored in OW and only excess items are stored in RW. This is the same as we discussed before. In order to reduce the inventory cost, the RW was emptied first by transporting the stock from RW to OW in a continuous release pattern. That is to say, the demand of items was met at OW only. Then the paper developed two-warehouse inventory model with the consideration of inflation, time-dependent demand, partially backlogging, and time-value of money. Rong et al. [95] studied the similar problem as Dey et al. [94] did.

As we stated at the beginning of 3.2, in order to reduce inventory cost, a considerable number of studies on twowarehouse inventory problems for deteriorating items follow the rule of LIFO (last in first out). But Lee [96] held a different opinion in this respect; he believed that in the RW, especially in the public warehouse, the vendor of the warehouse carried a lower operating cost because of well equipment set ups, learning effect of trained workers, and economies of scale. What's more, in the buyer's market more and more warehouses have to offer valued added service with completive lower prices to attract customers. So the assumption that the holding costs are higher in the rented warehouses is not so reasonable. Besides all stated above, the researcher still believed that for deteriorating items, under the rule of LIFO, the cost of item deterioration and related opportunity cost may far exceed the cost saving benefit derived from the rent (on the condition that the holding costs in the rented warehouses are really higher than those in the OW). So it may 
be more reasonable to operate under the rule of FIFO. In his study, Chun Chen Lee reconsidered the LIFO model proposed by Pakkala and Achary [97] and then developed a FIFO model. Comparison of the two models showed that the FIFO model was less expensive than the LIFO model, on the condition that the mixed effects of deterioration and holding cost in RW are less than that of the OW. Niu and Xie [98]then amended the model proposed by Chun Chen Lee and so the modified LIFO model always had a lower cost than the FIFO model proposed by Pakkala and Achary.

It is a common phenomenon that seasonal or cyclical items are often purchased in large quantities and so the study of two-warehouse inventory is of important practical significance for these items.

\subsection{Production-Inventory Study for Deteriorating Items}

For deteriorating items manufacturing, decision makers should take inventory into consideration in production policy making. Proposing an efficient production-inventory decision is conducive to enhancing the competitiveness of enterprises [43]. Many researchers have extensively studied in this area, such as Goyal and Gunasekaran [99], Jiang and Du [100], Chen et al. [101], Gong and WANG [102], Maity et al. [103] and so on. With the assumption that the demand rate, production rate, and deteriorating rate are all constant, Jui-Jung Liao [104,105] established a production-inventory model for deteriorating items under the condition of the supplier providing the retailer with trade credit. Teng and Chang [106] established an economic production quantity (EPQ) model for deteriorating items when the demand rate was dependant on both the stock level and the selling price per unit, and in which the deteriorating rate was constant. The paper also provided the necessary conditions to decide the optimal solution which maximized profit of the EPQ model. From the model, decision makers could get aid in developing the optimal price and in production run time decisions.

In all the models stated above, shortages are not allowed. In conditions of shortages, each production- inventory cycle in the planning horizon can be described in more detail. Generally speaking, each production- inventory cycle can be divided into four stage, there are production starts_— consumption stage; production stops- consumption stage; production stops—shortage stage, and production starts_—shortage stage. The order of the four stages depends mainly on the shortage occurring at the beginning or the end of the cycle. Lin Hsinyi et al. [107] established a production_-inventory model with constant production rate, demand rate and deteriorating rate. Shortages are allowed and occur at the start of each cycle. So the production__ inventory cycle can be divided into production stops_—shortage stage; production starts_—shortage stage; production—_ consumption stage; production stops_— consumption stage. From the model, we can get the number of production-inventory cycles and the starting point of the four stages in every cycle. Incorporating these parameters with the known constant production rate, we can get the optimal production-inventory policy. Zhou et al. [108] also considered production-inventory problem in which each cycle of a production-inventory schedule starts with replenishment and ends with a shortage. In this model, time-dependent demand was taken into consideration. In the research of Sana et al. [109] and Zhou and Gu [110], shortages are allowed and occur at the end of a cycle. So the cycle consists of four stages as below: production starts-consumption stage; production stops__ consumption stage; production stops_ shortage stage and production starts- shortage stage. With the consideration of time variable demand and constant deteriorating rate, the optimal production-inventory policy was studied.

All the deteriorating rates in the models stated above are constant and some researchers have studied timedependent deteriorating rates. With the time-varying demand and deteriorating rate, both Skouri and Papachristos [111] and Chen et al. [112] developed a production-inventory model in which the storages are allowed at the beginning of the cycle. In contrast, in Manna and Chaudhuri [114] and Balkhi's research [113], shortages are also allowed but occur at the end of each cycle. Abad [116] studied the pricing and lot-sizing problem for deteriorating items under the conditions of finite production, partial backlogging, and lost sale. Teng et al [115]extend P.L. Abad's model by adding the backlogging cost and the cost of lost goodwill. Then, the paper made a comparison between Abad's model [116] and Goyal's model [117] in which shortages occur at the beginning of the cycle. The numerical results show that there is no dominant one between these two models. The paper also provides certain conditions under which one model had more net profit per unit time than the other.

\section{Deteriorating Items Inventory in the Supply Chain}

With the integration of the global economy, there is more and more diversity and uncertainty in the market. In order to deal with the uncertainties in the market and respond quickly to the diverse and personal demand of customer, enterprises need to cooperate with each other in the form of an integrated supply chain. The traditional inventory theory can not adapt to the current situation any more, the inventory problem should be considered in the supply chain. The deterioration of the deteriorating items makes it is important for the relative firms in the supply chain to make the optimal inventory policy together to minimize the total inventory cost across the supply chain. In the following part of the paper, we will discuss the current studies on the deteriorating items inventory in the supply chain. 


\subsection{Deterministic Deteriorating Items Inventory in the Supply Chain}

Yang and Wee $[118,119]$ have conducted research on the inventory policy for deteriorating item in the supply chain including a single-vendor and multi-buyers. Yang and Wee [118] developed a multi-lot-size production and inventory model for deteriorating items with constant production and demand rates. In this paper, a supply chain including a single-vendor and multi-buyers was established and the supplier was dominant in the supply chain. The supplier delivered the goods in the form of JIT and the aim of the paper was to find the optimal production-inventory policy on the basis of minimizing the inventory cost in the supply chain. According to the numerical results, the optimal policy using the integrated approach can reduce the total cost for the producer and the buyer. However, the producer's cost is higher in the form of supply chain integration than the independent decision without considering the buyer's perspective. So in order to maintain the stability of the supply chain, the buyers have to supply some kinds of incentives to the supplier. Then Yang and Wee [119] established a collaborative inventory system of single vendor and single buyer with the price-dependent demand, shortages are not allowed in the system. The paper developed different inventory models under the cases of vendor and buyer making decisions respectively; vendor and buyer making decisions together but no incentives are incorporated in the decisions; the two parties making decisions together and the vendor providing trade credit to the buyer. The numerical results showed that among the three cases, the profit in the first case was the smallest. The profit in the second case was the same with the one in the third case and the profit in the second and third case was larger than the one in the first case. As is well known to us all, the optimal solution for the whole system is not always beneficial to all the players in the system and in fact in the second case, the buyer's profit was seriously damaged and so the buyer will refuse to cooperate with the supplier. While in the third case, the trade credit was incorporated in the system and it helped to share profit between the two parties. Compared to the first case, both vendor and buyer can get the extra profit and the supply chain was stable in this case.

Compared to the deteriorating items inventory study in a single enterprise, the inventory studies in the supply chain have to emphasize how to maintain the stability of the whole system while achieving the minimum of inventory costs in the supply chain. Therefore, researchers focused on supply chain coordination mechanism in the deteriorating items inventory problem study. LI and HUANG [120] established a three-level supply chain including vendor, manufacture, and retailer in which the manufacture is dominant. The paper developed two dif- ferent models; in first case all the firms in the supply chain make decisions independently, and in the second the firms make decisions together. In the case of non-integrated decision-making, the manufacturer was the dominant member in the supply chain; the ordering policies of vendor and supplier were subject to the policy made by manufacturer, so the aim of the model is to minimize the costs of the manufacturer. While in the case of integration, the aim of the optimal production and inventory policy making is to minimize the costs of the whole supply chain. According to the numerical results, the costs in the case of integration is lower than that in the case of non-integration, but the optimal solution for the whole system is not beneficial to all the members in the supply chain. In order to realize integration in the supply chain, the paper introduced the cost sharing mechanism in the supply chain to guarantee the implementation of integration and win-win among members. Both An and Luo [121], Qin and Guo [122] studied the effect of quantity discount across the supply chain and their studies showed that quantity discount is a useful coordination method among supply chain members. In Qin and Guo's study [122], quantity discount was used as a coordination mechanism to achieve the stability of supply chain. As the leader of the supply chain, the supplier develops an optimal discount price policy and shares the policy with the customer. Then the customer determines his unit selling price and sales volume. The numerical example showed that when the supplier determined the quantity discount, both the supplier and customer's profit increase.

\subsection{Stochastic Deteriorating Items Inventory in the Supply Chain}

The studies on stochastic deteriorating items inventory in the supply chain at present are much less than the ones on the deterministic deteriorating items inventory. Du et al. [123] studied the deteriorating item stock replenishment and shipment policy for vendor-managed inventory (VMI) system with the assumption that the demand process follows a typical Poisson process. This research is important to practical applications and we will discuss the paper in detail.

In the circumstances of vendor-managed inventory, the vendor acts as a supply chain manager and plans inventory and shipment scheduling from the perspective of the whole supply chain rather than obey orders passively and arrange shipments respectively. The aim of VMI is to develop an inventory and shipment policy in which the vendor can meet the demand of the retailers and determine their own inventory replenishment policy at the same time. The policy can realize the aim of minimizing the total costs in the supply chain. This is the so called integrated shipment which means that gathering the small amount of order quantities from downstream enterprises into a large quantity and then make integrated shipping scheduling. The 
integrated shipment policy can reduce relative costs in the inventory and shipment delivery [124].

Du et al. [123] made a comprehensive study on the integrated shipment policy under the circumstances of vendor-managed inventory for the deteriorating items. The paper established a supply chain system which includes a manufacturer, a vendor, and many retailers located in different regions and the demand process follows a typical Poisson process. In the mode of VMI, the vendor is responsible for replenishing the retailers' inventory and arranging the corresponding shipment schedules. The purpose of the study is to make a joint decision in those two areas stated above. There are three parameters $(\mathrm{Q}, \mathrm{q}$, $\mathrm{T}$ ) in the integrated shipment policy, among them the $\mathrm{Q}$ stands for the order-up to level, $\mathrm{q}$ stands for planned shipments and $\mathrm{T}$ is the planned delivery period. The policy operates as below: vendor delivery order quantities which accumulate during the predetermined replenish cycle $\mathrm{T}$ is shipped to the retailer at the end of the cycle. However, if the accumulated order quantity reaches the amount of q, which is also a predetermined parameter, before the end of the cycle, the vendor will also, delivery items to the retailers. Every time a delivery is planned, the vendors have to decide whether the inventory for each item needs to be replenished, and if it needs replenishment, what is the replenishment amount. It must be guaranteed that the inventory level of the vendor is equal to or more than the order-up to level parameter $\mathrm{Q}$ after delivery.

Integrated delivery is an important issue which must be considered when implementing vendor-managed inventory. The studies on the integrated delivery problem for deteriorating items can aid the vendors to make relevant decisions about delivery and replenishment and so can help reduce the costs in the supply chain.

\section{Conclusions}

The inventory problems for deteriorating items have attracted more and more attention and many researchers have conducted extensive studies in this area. In this paper, from a different perspective, we have tried to make a review on deteriorating inventory literatures after Raafat [4]'s and Goyal's reviews [5]. According to the literatures discussed in this paper, we can draw some useful conclusions. Subsequent subsections present significant findings, the gaps identified in the research and future directions of the research in the relevant area.

\subsection{Significant Findings}

1) According to the research scope, the current studies can be divided into two categories, the first category studies the deteriorating items inventory problems in a single enterprise and the second category studies the deteriorating items inventory in supply chain. From the perspective of quantity, there are much less studies in the second category compared with those belong to the first category. The study on deteriorating items inventory problems is a new research area compared with the inventory research on common items and so the total research amount is far less than the traditional one.

2) Also, studies in the single enterprise category are less complex than the second category of the integrated supply chain. Two situations are included: first, from the perspective of the number of key factors involved in the model, there are always fewer factors involved in the supply chain deteriorating inventory models. For example, in the first category inventory models, besides demand and deteriorating rate, other factors such as price discount, allow shortage or not, inflation, time-value of money and so on are always combined in the model; then in the second category, in order to simplify the situation, always less factors considered.

3) Then when it comes to a single factor, the models in supply chain circumstances always consider easier situation of the same factor. Take demand for example, Many studies in the second category especially those under the circumstances of multi-echelon supply chain involve constant demand rate in the inventory model. Only few of the studies in the second category take stochastic demand into consideration for it is really hard to deal with in these kinds of models. For the first category, constant demand is the focus of the early stage and now more and more studies begin to research other kinds of demand, such as time-dependent demand, inventory level- dependent demand, price-dependent demand, and even stochastic demand.

4) Deteriorating rate is another key factor in the study of deteriorating items inventory and there are also several kinds of deteriorating rate in the present study, such as constant deteriorating rate, deteriorating rate is a linear increasing function of time, deteriorating rate is two- parameter Weibull distributed, and deteriorating rate is three-parameter Weibull distributed. Among them, constant deteriorating rate is the easiest one and the three-parameter Weibull distribution deteriorating rate is more complex. Some studies which belong to the first category have made extensive study in this factor and some studies even involve the three-parameter Weibull distribution deteriorating rate; the relatively complex one in the model. For the second category, constant deteriorating rate is the most common one in model establishment.

\subsection{Future Directions of the Research}

1) As we all know, in order to respond quickly to the diversity and uncertainty in the market, all the enterprises should be part of a supply chain and so it is more reasonable to consider inventory problems in a supply chain. The diversity and uncertainty that a supply chain will face are much more complex than a single enterprise so more factors and more complex situation of a single factor should 
be taken into consideration of deteriorating inventory problems in a supply chain. Only in this way, can the studies supply practical measurements to managers.

2) In practical situation, the information about inventory is not always precise, most of the time it is vague or imprecise. So it is more reasonable to develop some fuzzy, stochastic and dynamic research methods and this is also the future trend of the deteriorating inventory study.

3) Luckily, many researchers have studied inventory under fuzzy circumstances. Katagiri and Ishii [125] established inventory models for deteriorating items with fuzzy shortage cost and due to the fuzziness of relative parameters; the expected profit function in the study is represented with a fuzzy set. Chen and Ouyang [126] established a fuzzy inventory model for deteriorating items with permissible delay in payment. The study involved the fuzzy carrying cost rate, fuzzy interest paid rate, and fuzzy interest earned rate simultaneously in the model. With the assumption of constant demand and deteriorating rate, Arindam Roy, Samarjit Kar and Manoranjan Maiti [127], Arindam Roy, Manas Kumar Maiti, Samarjit Kar and Manoranjan Maiti [128] established an EOQ model which involved imprecise parameters, such as fuzzy inventory cost, fuzzy storage area, and so on. The purpose of their research was to minimize the total inventory cost.

It is recommended that more and more researchers begin to study deteriorating items inventory problems in supply chain with fuzzy, stochastic and dynamic research methods, only in this way, can the researches be applied to practice. It is hoped that this paper can provide an overview of the deteriorating items inventory in the recent years and so act as a cornerstone for future study in this field.

\section{Acknowledgements}

This research was supported by The Research on Process Optimization of Cold Chain Logistics Based on Food Safety of Foundation of Beijing Jiaotong University (2007XM018).

\section{REFERENCES}

[1] H. M. Wee, "Economic production lot size model for deteriorating items with partial back ordering [J]," Compute \& Industrial Engineering, Vol. 24, No. 3, pp. 449458, 1993

[2] T. M. Whitin, "Theory of inventory management," Princeton University Press, Princeton, NJ, pp. 62-72, 1957

[3] P. M. Ghare and G. P. Schrader, "A model for an exponentially decaying inventory [J],” Journal of Industrial Engineering, Vol. 14, No. 5, 1963.

[4] F. Raafat, survey of literature on continuously deteriorat- ing inventory model [J],” Journal of the Operational Research Society, Vol. 42, No. 1, pp. 27-37, 1991.

[5] S. K. Goyal and B. C. Giri, "Recent trends in modeling of deteriorating inventory [J]," European Journal of Operational Research, Vol. 134, No. 1, pp. 1-16, 2001

[6] K.-J. Chung and C.-N. Lin, “Optimal inventory replenishment models for deteriorating items taking account of time discounting [J],” Computers \& Operations Research, Vol. 28, No. 1, pp. 67-83, 2001.

[7] L. Benkherouf, A. Boumenir, and L. Aggoun, "A diffusion inventory model for deteriorating items [J],” Applied Mathematics and Computation, Vol. 138, No. 1, pp. 2139, 2003.

[8] B. C. Giri, T. Chakrabarty, and K. S. Chaudhuri, "A note on a lot sizing heuristic for deteriorating items with timevarying demands and shortages [J]," Computers \& Operations Research, Vol. 27, No. 6, pp. 495-505, 2000.

[9] J.-T. Teng, H.-J. Chang, C.-Y. Dye, and C.-H. Hung, “An optimal replenishment policy for deteriorating items with time-varying demand and partial backlogging [J],” Operations Research Letters, Vol. 30, pp. 387-393, 2002.

[10] K.-J. Chung, P. Chu, and S.-P. Lan, “A note on EOQ models for deteriorating items under stock dependent selling rate [J]," European Journal of Operational Research, Vol. 124, pp. 550-559, 2000

[11] B. C. Giri and K. S. Chaudhuri, "Deterministic models of perishable inventory with stock-dependent demand rate and nonlinear holding cost [J]," European Journal of Operational Research, Vol. 105, No. 3, pp. 467-474, 16 March 1998.

[12] D. K. Bhattachaya, “On multi-item inventory [J],” European Journal of Operational Research, Vol. 162, pp. 786791, 2005.

[13] K.-S. Wu, L.-Y. Ouyang, and C.-T. Yang, “An optimal replenishment policy for non-instantaneous deteriorating items with stock-dependent demand and partial backlogging [J],” International Journal of Production Economics, Vol. 101, pp. 369-384, 2006.

[14] H.-M. Wee and S.-T. Law, "Economic production lot size for deteriorating items taking account of the time-value of money [J],” Computers \& Operations Research, Vol. 26, pp. 545-558, 1999.

[15] R. M. Hill, "Inventory model for increasing demand followed by level demand,” Journal of the Operational Research Society, Vol. 46, pp. 1250-1259, 1995.

[16] B. Mandal and A. K. Pal, "Order level inventory system with ramp type demand rate for deteriorating items," Journal of Interdisciplinary Mathematics, No. 1, pp. 49-66. 1998.

[17] P. S. H. Deng, R. H.-J. Lin, and P. Chu, “A note on the inventory models for deteriorating items with ramp type demand rate [J]," European Journal of Operational Research, Vol. 178, No. 1, pp. 112-120, 2007.

[18] K. Skouri, I. Konstantaras, S. Papachristos, and I. Ganas, "Inventory models with ramp type demand rate, partial backlogging and Weibull deterioration rate [J],” European 
Journal of Operational Research, 2007.

[19] Y. K. Shah and M. C. Jaiswal, "An order-level inventory model for a system with constant rate of deterioration," Opsearch, Vol. 14, pp. 174-184, 1977.

[20] S. P. Aggarwal, "A note on an order-level inventory model for a system with constant rate of deterioration," Opsearch, Vol. 15, pp. 184-187, 1978.

[21] G. Padmanabhana and P. Vratb, "EOQ models for perishable items under stock dependent selling rate [J]," European Journal of Operational Research, Vol. 86, No. 2, pp. 281-292, 19 October 1995,

[22] A. K. Bhunia and M. Maiti, “An inventory model of deteriorating items with lot-size dependent replenishment cost and a linear trend in demand [J]," Applied Mathematical Modelling, Vol. 23, pp. 301-308, 1999.

[23] A. K. Bhunia and M. Maiti, "Deterministic inventory model for deteriorating items with finite rate of replenishment dependent on inventory level [J]," Computers \& Operations Research, Vol. 25, No. 11, pp. 997-1006, 1 November 1998.

[24] S. Mukhopadhyay, R. N. Mukherjee, and K. S. Chaudhuri, "Joint pricing and ordering policy for a deteriorating inventory [J],” Computers \& Industrial Engineering, Vol. 47, pp. 339-349, 2004.

[25] H.-M. Wee, "Deteriorating inventory model with quantity discount, pricing and partial backordering [J]," International Journal of Production Economics, Vol. 59, pp. 511-518, 1999

[26] N. K. Mahapatra, “Decision process for multiobjective, multi-item production-inventory system via interactive fuzzy satisficing technique $[\mathrm{J}]$," Computers and Mathematics with Applications, Vol. 49, pp. 805-821, 2005.

[27] T. Chakrabarty, B. C. Giri, and K. S. Chaudhuri, "An EOQ model for items with weibull distribution deterioration, shortages and trended demand: an extension of philip’s model [J],” Computers \& Operations Research, Vol. 25, No. 7-8, pp. 649-657, July 1998.

[28] P. L. Abad, "Optimal price and order size for a reseller under partial backordering [J]," Computers \& Operations Research, Vol. 28, pp. 53-65, 2001.

[29] F. W. Gu and S. Y. Zhou, “A replenishment policy for deteriorating items which are permissible delay in payment [J]," Logistics Technology, Vol. 26, No. 9, pp. 4851, 2007.

[30] M. K. Salameh, S. A. Fakhreddine, and N. Noueihed, "Effect of deteriorating items on the instantaneous replenishment model with backlogging [J]," Computers \& Industrial Engineering, Vol. 37, pp. 261-264, 1999.

[31] Y.-W. Zhou and H.-S. Lau, "An economic lot-size model for deteriorating items with lot-size dependent replenishment cost and time-varying demand [J],” Applied Mathematical Modelling, Vol. 24, pp. 761-770, 2000.

[32] Y.-W. Zhou, H.-S. Lau, and S.-L. Yang, “A new variable production scheduling strategy for deteriorating items with time-varying demand and partial lost sale [J]," Computers \& Operations Research, Vol. 30, pp. 1753-1776,
2003.

[33] K. Skouri and S. Papachristos, "A continuous review inventory model, with deteriorating items, time-varying demand, linear replenishment cost, partially time-varying backlogging [J],” Applied Mathematical Modelling, Vol. 26, pp. 603-617, 2002.

[34] S.-P. Wang, “An inventory replenishment policy for deteriorating items with shortages and partial backlogging [J],” Computers \& Operations Research, Vol. 29, pp. 2043-2051, 2002

[35] C.-Y. Dye, "Joint pricing and ordering policy for a deteriorating inventory with partial backlogging [J],” Omega, Vol. 35, pp. 184-189, 2007.

[36] A. M. M. Jamal, B. R. Sarker, and S. J. Wang, "Optimal payment time for a retailer under permitted delay of payment by the wholesaler [J]," International Journal of Production Economics, Vol. 66, pp. 59-66, 2000.

[37] X. P. Song and X. Q. Cai, “On optimal payment time for retailer under permitted delay of payment by the wholesaler [J]," International Journal of Production Economics, Vol. 103, pp. 246-251, 2006.

[38] L.-Y. Ouyang, K.-S. Wu, and C.-T. Yang, "A study on an inventory model for non-instantaneous deteriorating items with permissible delay in payments [J]," Computers \& Industrial Engineering, Vol. 51, pp. 637-651, 2006.

[39] K.-J. Chung and J.-J. Liao, "Lot-sizing decisions under trade credit depending on the ordering quantity [J]," Computers \& Operations Research, Vol. 31, pp. 909-928, 2004.

[40] K.-J. Chung and J.-J. Liao, “The optimal ordering policy in a DCF analysis for deteriorating items when trade credit depends on the order quantity [J],” International Journal of Production Economics, Vol. 100, pp. 116-130, 2006.

[41] L.-Y. Ouyang, J.-T. Teng, S. K. Goyal, and C.-T. Yang, "An economic order quantity model for deteriorating items with partially permissible delay in payments linked to order quantity [J],” European Journal of Operational Research, 2008.

[42] C. Zhang, G.-X. DAI, G.-H. Han, and M. Li, "Study on optimal inventory model for deteriorating items based on linear trade credit [J]," Journal of Qingdao University (Natural Science Edition), Vol. 20, No. 3, pp. 70-74, 2007.

[43] X. W. Wen and L.-J. Zuo, “A review of development of deteriorating inventory theory research [J]," Journal of South China Agricultural University: Social Science Edition, Vol. 6, No. 4, pp. 46-52, 2007.

[44] H.-C. Liao, C.-H. Tsai, and C.-T. Su, "An inventory model with deteriorating items under inflation when a delay in payments is permissible [J],” International Journal of Production Economics, Vol. 63, pp. 207-214, 2000.

[45] K.-J. Chung and S.-F. Tsai, "Inventory systems for deteriorating items with shortages and a linear trend in demand-taking account of time value [J]," Computers \& Operations Research, Vol. 28, pp. 915-934, 2001.

[46] J.-M. Chen, “An inventory model for deteriorating items with time-proportional demand and shortages under inflation and time discounting $[\mathrm{J}]$,” International Journal of 
Production Economics, Vol. 55, No. 1, pp. 21-30, 10 June 1998,

[47] I. Moon, B. C. Giri, and B. Ko, "Economic order quantity models for ameliorating/deteriorating items under inflation and time discounting [J]," European Journal of Operational Research, Vol. 162, pp. 773-785, 2005

[48] B. R. Sarker, A. M. M. Jamal, and S. J. Wang, "Supply chain models for perishable products under inflation and permissible delay in payment [J]," Vol. 27, pp. 59-75, 2000.

[49] C.-T. Chang, "An EOQ model with deteriorating items under inflation when supplier credits linked to order quantity [J]," International Journal of Production Economics, Vol. 88, pp. 307-316, 2004.

[50] K.-J. Chung and J.-J. Liao, “The optimal ordering policy in a DCF analysis for deteriorating items when trade credit depends on the order quantity [J]," International Journal of Production Economics, Vol. 100, pp. 116-130, 2006.

[51] K.-N. Huang and J.-J. Liao, “A simple method to locate the optimal solution for exponentially deteriorating items under trade credit financing [J]," Computers and Mathematics with Applications, Vol. 56, No. 4, pp. 965-977, August 2008.

[52] C. Zhang, G.-X. Dai, G.-H. Han, and M. Li, "Study on inventory model for deteriorating items based on trade credit and cash discount $[\mathrm{J}]$,” Operations Research and Management Science, Vol. 16, No. 6, pp. 33-37,41, 2007.

[53] S.-D. Wang and J.-P. Wang, "A multi-stage optimal inventory model for deteriorating items by considering time value and inflation rate [J]," Operations Research and Management Science, Vol. 14, No. 6, pp. 142-148, 2005.

[54] S. Panda, S. Senapati, and M. Basu, "Optimal replenishment policy for perishable seasonal products in a season with ramp-type time dependent demand [J]," Computers \& Industrial Engineering, Vol. 54, pp. 301-314, 2008.

[55] S. Papachristos and K. Skouri, "An optimal replenishment policy for deteriorating items with time-varying demand and partial-exponential type-backlogging [J],” Operations Researh Letters, Vol. 27, pp. 175-184, 2000.

[56] P. Chu and P. S. Chen, “A note on inventory replenishment policies for deteriorating items in an exponentially declining market [J]," Computers \& Operations Research, Vol. 29, pp. 1827-1842, 2002.

[57] S. Khanra and K. S. Chaudhuri, “A note on an order-level inventory model for a deteriorating item with time-dependent quadratic demand [J]," Computers \& Operations Research, Vol. 30, pp. 1901-1916, 2003.

[58] “A comparison among various partial backlogging inventory lot-size models for deteriorating items on the basis of maximum profit [J]," International Journal of Production Economics, Vol. 96, pp. 119-128, 2005.

[59] C.-Y. Dye, H.-J. Chang, and J.-T. Teng, “A deteriorating inventory model with time-varying demand and shortage-dependent partial backlogging [J],” European Journal of Operational Research, Vol. 172, pp. 417-429, 2006.

[60] R. Gupta and P. Vrat, "Inventory model with multi-items under constraint systems for stock dependent consumption rate [J],” Operations Research, Vol. 24, pp. 41-42.

[61] B. N. Mandal and S. Phaujdar, "An inventory model for deteriorating items and stock-dependent consumption rate [J],” Journal of the Operational Research Society, Vol. 40, pp. 483-488, 1989.

[62] G. Padmanabhan and P. Vrat, "EOQ models for perishable items under stock dependent selling rate [J]," European Journal of Operational Research, Vol. 86, No. 2, pp. 281-292, 19 October 1995.

[63] C.-Y. Dye and L.-Y. Ouyang, "An EOQ model for perishable items under stock-dependent selling rate and time-dependent partial backlogging [J],” European Journal of Operational Research, Vol. 163, pp. 776-783, 2005.

[64] K.-L. Hou, “An inventory model for deteriorating items with stock-dependent consumption rate and shortages under inflation and time discounting [J]," European Journal of Operational Research, Vol. 168, pp. 463-474, 2006.

[65] Z.-H. Peng and T. Peng, "Pricing and inventory model based on quantity discounts of deteriorating goods [J]," Journal of University of Shanghai For Science and Technology, Vol. 26, No. 6, pp. 565-568,574, 2004.

[66] J.-T. Teng, C.-T. Chang, and S. K. Goyal, "Optimal pricing and ordering policy under permissible delay in payments [J],” International Journal of Production Economics, Vol. 97, pp. 121-129, 2005.

[67] Y.-Y. Qin, H.-W. Tang, and C.-H. Guo, “On an inventory model for deteriorating items of price-sensitive demand and quantity discounts [J],” Operations Research and Management Science, Vol. 15, No. 4, pp. 22-26, 2006.

[68] C. K. Jaggi, K. K. Aggarwal, and S. K. Goel, “Optimal orser policy for deteriorating items with inflation induced demand [J]," International Journal of Production Economics, Vol. 103, pp. 707-714, 2006.

[69] Z. T. Balkhi and L. Benkherouf, “On an inventory model for deteriorating items with stock dependent and time-varying demand rates [J]," Computers \& Operations Research, Vol. 31, pp. 223-240, 2004.

[70] A. K. Pal, A. K. Bhunia, and R. N. Mukherjee, "Optimal lot size model for deteriorating items with demand rate dependent on displayed stock level (DSL) and partial backordering [J],” European Journal of Operational Research, Vol. 175, pp. 977-991, 2006.

[71] P.-H. Hsu, H. M. Wee, and H.-M. Teng, “Optimal ordering decision for deteriorating items with expiration date and uncertain lead time [J],” Computers \& Industrial Engineering, Vol. 52, pp. 448-458, 2007.

[72] Z.-L. Wen, Y. Zhu, J. Li, and C.-M. Xu, “An inventory model for deteriorating items with backorder dependent lost rate and time value of money [J],” Journal of Guangxi University of Technology, Vol. 18, No. 3, pp. 28-32, 2007.

[73] H.-M. Wee and S.-T. Law, "Replenishment and pricing policy for deteriorating items taking into account the time-value of money [J],” International Journal of Production Economics, Vol. 71, pp. 213-220, 2001. 
[74] S. Papachristos and K. Skouri, "An inventory model with deteriorating items, quantity discount, pricing and timedependent partial backlogging [J],” International Journal of Production Economics, Vol. 83, pp. 247-256, 2003.

[75] C.-Y. Dye, T.-P. Hsieh, and L.-Y. Ouyang, "Determining optimal selling price and lot size with a varying rate of deterioration and exponential partial backlogging [J]," European Journal of Operational Research, Vol. 181, pp. 668-678, 2007.

[76] C.-Y. Dye, L.-Y. Ouyang, and T.-P. Hsieh, "Inventory and pricing strategies for deteriorating items with shortages: A discounted cash flow approach [J]," Computers \& Industrial Engineering, Vol. 52, pp. 29-40, 2007.

[77] C.-T. Chang, L.-Y. Ouyang, and J.-T. Teng, “An EOQ model for deteriorating items under supplier credit linked to ordering quantity [J]," Applied Mathematical Modelling, Vol. 27, pp. 983-996, 2003.

[78] J.-J. Liao, “A note on an EOQ model for deteriorating items under supplier credit linked to ordering quantity [J],” Applied Mathematical Modelling, Vol. 31, pp. 16901699, 2007.

[79] W.-L. Huang and S. Huang, "An inventory model for items with weibull distribution deterioration rate under stock-dependent demand [J],” Industrial Engineering and Management, Vol. 2, pp. 72-75,101, 2007.

[80] S. Kalpakam and S. Shanthi, "A perishable system with modified base stock policy and random supply quantity [J],” Vol. 39, pp. 79-89, 2000.

[81] S. Kalpakam and S. Shanthi, "A perishable inventory system with modified(S-1,S)policy and arbitrary processing times [J],” Computers \& Operations Research, Vol. 28, pp. 453-471, 2001.

[82] G.-P. Zhu, “Optimal inventory model for single perishable item [J]," Journal of Ningxia University (Natural Science Edition), Vol. 22, No. 1, pp. 15-16, 2001.

[83] L.-F. Li, P.-Q. Huang, and J.-W. Luo, "A study of inventory management for deteriorating items [J]," Systems Engineering, Vol. 22, No. 3, pp. 25-30, 2004.

[84] X.-H. Xu and R.-J. Li, "A two-warehouse inventory model for deteriorating items with time-dependent demand [J],” Logistics Technology, No. 1, pp. 37-40, 2006.

[85] Z. L. Yang, Z. Y. Wu, and S. L. Yang, “An economic model and its optimal solution for deteriorating items with two warehouses and parabollic demand [J]," Systems Engineering Theory Methodology Applications, No. 4, pp. 376-378, 2005.

[86] S. L. Yang and Y. W. Zhou, “Two-warehouse inventory model: Considering time-varying demand and price discounts [J]," Journal of Systems Engineering, Vol. 18, No. 6, pp. 498-505, 2003.

[87] L. Benkherouf, “A deterministic order level inventory model for deteriorating items with two storage facilities [J],” International Journal of Production Economics, Vol. 48, No. 2, pp. 167-175, 24 January 1997.

[88] K. V. S. Sarma, “A deterministic order level inventory model for deteriorating items with two storage facilities
[J],” European Journal of Operational Research, Vol. 29, No. 1, pp. 70-73, April 1987.

[89] T. P. M. Pakkala and K. K. Achary, "A deterministic inventory model for deteriorating items with two warehouses and finite replenishment rate [J],” European Journal of Operational Research, Vol. 57, No. 1, pp. 71-76, 25 February 1992.

[90] H.-L. Yang, "Two-warehouse inventory models for deteriorating items with shortages under inflation [J],” European Journal of Operational Research, Vol. 157, pp. 344-356, 2004.

[91] H.-L. Yang, "Two-warehouse partial backlogging inventory models for deteriorating items under inflation [J]," International Journal of Production Economics, Vol. 103, pp. 362-370, 2006.

[92] H. Qiu and L. Liang, "A two-warehouse inventory model with delay in payment [J],” Systems Engineering, Vol. 25, No. 2, pp. 46-50, 2007.

[93] X.-H. Xu and R.-J. Li, “A two-warehouse inventory model for deteriorating items with time-dependent demand [J],” Logistics Technology, No. 1, pp. 37-40, 2006.

[94] J. K. Dey, S. K. Mondal, and M. Maiti, "Two storage inventory problem with dynamic demand and interval valued lead-time over finite time horizon under inflation and time-value of money [J]," European Journal of Operational Research, Vol. 185, pp. 170-194, 2008.

[95] M. Rong, N. K. Mahapatra, and M. Maiti, "A two warehouse inventory model for a deteriorating item with partially/fully backlogged shortage and fuzzy lead time [J]," European Journal of Operational Research, Vol. 189, pp. 59-75, 2008.

[96] C. C. Lee, "Two-warehouse inventory model with deterioration under FIFO dispatching policy [J],” European Journal of Operational Research, Vol. 174, pp. 861-873, 2006.

[97] T. P. M. Pakkala and K. K. Achary, "A deterministic inventory model for deteriorating items with two warehouses and finite replenishment rate [J]," European Journal of Operational Research, Vol. 57, No. 1, pp. 71-76, 25 February 1992.

[98] N. Bo and J. X. Xie, "A note on 'Two-warehouse inventory model with deterioration under FIFO dispatching policy' [J],” European Journal of Operational Research, Vol. 190, pp. 571-577, 2008.

[99] S. K. Goyal and A. Gunasekaran, “An integrated production-inventory-marketing model for deteriorating items [J],” Computers \& Industrial Engineering, Vol. 28, No. 4, pp. 755-762, October 1995.

[100] D. L. Jiang and W. Du, “A study on two-stage production systems of perishable goods [J]," Journal of Southwest Jiaotong University, Vol. 33, No. 4, pp. 430-435, 1998.

[101] S.-J. Chen, S.-P. Chen, and X.-B. Liu, “A production-inventory model for deteriorating items [J]," Journal of Zhaoqing University, Vol. 23, No. 2, pp. 66-68, 2002.

[102] Z.-J. Gontg and C.-Q. Wang, “A production-inventory arrangement model for deteriorating items in a linear in- 
creasing market $[\mathrm{J}]$,” Logistics Technology, No. 10, pp. 6-8, 2005.

[103] A. K. Maity, K. Maity, S. Mondal, and M. Maiti, “A chebyshev approximation for solving the optimal production inventory problem of deteriorating multi-item [J]," Mathematical and Computer Modelling, Vol. 45, pp. 149161, 2007.

[104] J.-J. Liao, “On an EPQ model for deteriorating items under permissible delay in payments [J]," Applied Mathematical Modelling, Vol. 31, pp. 393-403, 2007.

[105] J.-J. Liao, “An EOQ model with noninstantaneous receipt and exponentially deteriorating items under two-level trade credit [J],” International Journal of Production Economics, Vol. 113, pp. 852-861, 2008.

[106] J.-T. Teng and C.-T. Chang, "Economic production quantity models for deteriorating items with price- and stockdependent demand [J]," Computers \& Operations Research, Vol. 32, pp. 297-308, 2005.

[107] H. Lin, X. W. Wen, and Q. L. Da, “Optimal production policy for deteriorating items with backlogging demand in stochastic production process [J]," Journal of Southeast University (Natural Science Edition), Vol. 37, No. 4, pp. 731-736, 2007.

[108] Y.-W. Zhou, H.-S. Lau, and S.-L. Yang, “A new variable production scheduling strategy for deteriorating items with time-varying demand and partial lost sale [J]," Computers \& Operations Research, Vol. 30, pp. 1753-1776, 2003.

[109] S. Sana, S. K. Goyal, and K. S. Chaudhuri, "A production-inventory model for a deteriorating item with trended demand and shortages [J]," European Journal of Operational Research, Vol. 157, pp. 357-371, 2004.

[110] S.-Y. Zhou and F.-W. Gu, "An optimal production-inventory policy for deteriorating items [J],' Logistics Technology, Vol. 26, No. 4, pp. 43-46, 2007.

[111] K. Skouri and S. Papachristos, "Optimal stopping and restarting production times for an EOQ model with deteriorating items and time-dependent partial backlogging [J],” International Journal of Production Economics, Vol. 81-82, pp. 525-531, 2003.

[112] J.-M. Chen andn L.-T. Chen, "Pricing and production lot-size/scheduling with finite capacity for a deteriorating item over a finite horizon [J]," Computers \& Operations Research, Vol. 32, pp. 2801-2819, 2005.

[113] Z. T. Balkhi, “On a finite horizon production lot size inventory model for deteriorating items: An optimal solution [J],” European Journal of Operational Research, Vol. 132, pp. 210-223, 2001.

[114] S. K. Manna and K. S. Chaudhuri, “An EOQ model with ramp type demand rate, time dependent deterioration rate, unit production cost and shortages [J],” European Journal of Operational Research, Vol. 171, pp. 557-566, 2006.

[115] J.-T. Teng, L.-Y. Ouyang, and L.-H. Chen, “A comparison between two pricing and lot-sizing models with partial backlogging and deteriorated items [J],” International
Journal of Production Economics, Vol. 105, pp. 190-203, 2007.

[116] P. L. Abad, “Optimal pricing and lot-sizing under conditions of perishability, finite production and partial backordering and lost sale [J]," European Journal of Operational Research, Vol. 144, pp. 677-685, 2003.

[117] S. K. Goyal and B. C. Giri, "The production-inventory problem of a product with time varying demand, production and deterioration rates [J]," European Journal of Operational Research, Vol. 147, pp. 549-557, 2003.

[118] P. C. Yang and H. M. Wee, "A single-vendor and multiple-buyers production -inventory policy for a deteriorating item [J],” European Journal of Operational Research, Vol. 143, pp. 570-581, 2002.

[119] P. C. Yang and H. M. Wee, “An integrated multi-lot-size production inventory model for deteriorating item [J]," Computers \& Operations Research, Vol. 30, pp. 671-682, 2003.

[120] L.-F. Li and P.-Q. Huang, "Study of production-inventory cooperation for deteriorating items on supply chain [J]," Journal of Shanghai Jiaotong University, Vol. 39, No. 3, pp. 464-467, 2005.

[121] Q. An and J.-W. Luo, "Study on coordination in supply chain inventory of perishable item with price discount [J],” Journal of Industrial Engineering, Vol. 21, No. 4, pp. 80-84, 2007.

[122] Y. Y. Qin and C. H. Guo, "Discount pricing model for easy-deteriorated items under elastic demand [J]," Chinese Journal of Management, Vol. 4, No. 2, pp. 163-168, 2007.

[123] S.-F. Du, L. Liang, J.-J. Zhang, and Z.-G. Lu, "Hybrid replenishment and dispatching policy with deteriorating item for VMI: Analytical model, optimization and simulation [J]," Chinese Journal of Management Science, Vol. 15, No. 2. pp. 64-69, 2007.

[124] L.-W. Liu and J.-R. Yuan, "Inventory and dispatch Models in VMI systems [J],” Chinese Journal of Management Science, Vol. 11, No. 5, pp. 31-36, 2003.

[125] H. Katagiri and H. Ishii, "Fuzzy inventory problems for perishable commodities [J]," European Journal of Operational Research, Vol. 138, PP. 545-553, 2002.

[126] L.-H. Chen and L.-Y. Ouyang, "Fuzzy inventory model for deteriorating items with permissible delay in payment [J],” Applied Mathematics and Computation, Vol. 182, pp. 711-726, 2006.

[127] A. Roy, S. Kar, and M. Maiti, “A deteriorating multi-item inventory model with fuzzy costs and resources based on two different defuzzification techniques [J]," Applied Mathematical Modelling, Vol. 32, pp. 208-223, 2008.

[128] A. Roy, M. K. Maiti, S. Kar, and M. Maiti, “An inventory model for a deteriorating item with displayed stock dependent demand under fuzzy inflation and time discounting over a random planning horizon [J],” Applied Mathematical Modelling, 2008. 